\title{
Production of Metallurgical Coke from Low Rank Coal Utilizing Wet Oxidation
}

\author{
Ryuichi ASHIDA, ${ }^{1) *}$ Atsushi HASHIMOTO, ${ }^{1)}$ Motoaki KAWASE ${ }^{1)}$ and Yukihiro KUBOTA ${ }^{2)}$ \\ 1) Department of Chemical Engineering, Kyoto University, Kyoto-daigaku Katsura, Nishikyo-ku, Kyoto, 615-8510 Japan. \\ 2) Process Research Laboratories, Nippon Steel \& Sumitomo Metal Corporation, 20-1 Shintomi Futtsu, Chiba, $293-8511$ \\ Japan.
}

(Received on December 10, 2018; accepted on June 7, 2019)

\begin{abstract}
Japanese steel industries, which are importing all coal resources required, are facing the necessity of increasing usable coal resources due to the recent rapid decrease of high-grade coking coal reserve and increase in its price. Low rank coals such as brown coals and subbituminous coals are promising substitutes for coking coals since they are abundant and cost-effective. However, the low rank coals generally have no thermoplasticity which is required for producing a coke with high mechanical strength using conventional coke ovens. In this work we have proposed to pretreat low rank coals by oxidative degradation reactions with aqueous oxidant such as hydrogen peroxide in order to convert them into thermoplastic coals suitable for coke making. An Australian brown coal was treated with hydrogen peroxide aqueous solution either at room temperature for 4,8 and $24 \mathrm{~h}$, or at $60^{\circ} \mathrm{C}$ for $0.5,1$ and $2 \mathrm{~h}$. The treated coals were then pelletized at room temperature and carbonized at $900^{\circ} \mathrm{C}$ to obtain cokes. It was found that the strength of the resulting cokes increased with increasing the oxidation time at $60^{\circ} \mathrm{C}$ and reached the level of a commercial coke, indicating that the treatment gave thermoplasticity to the coal. It was thus suggested that the wet oxidation was effective as a pretreatment for producing cokes from low rank coals.
\end{abstract}

KEY WORDS: brown coal; wet oxidation; metallurgical coke.

\section{Introduction}

In the situation where the coking coal reserve rapidly decreases and the coking coal price soars, a technology needs to be developed by which metallurgical coke can be produced using unused low-grade carbonaceous resources such as brown coals and subbituminous coals.

Brown coal reserves are large in such countries as Australia and Indonesia. However, it is difficult to transport them due to their high spontaneous combustibility. Therefore, brown coal is at the present days used only for electric power generation near the coal mining sites. Since brown coals often have the advantage of significantly low ash and sulfur contents, they have the high potential as a feedstock of clean fuels or materials.

Coking coals show thermoplasticity between around $400^{\circ} \mathrm{C}$ and $550^{\circ} \mathrm{C}$, which is required for producing a coke with high mechanical strength using conventional coke ovens. On the other hand, brown coals generally have no thermoplasticity in the temperature range. There are a lot of oxygen-containing functional groups such as hydroxyl and carboxyl groups in the brown coals, and they form strong hydrogen bondings to connect molecules. The oxygen-containing functional groups forming hydrogen bondings turn into cross-links when they decompose around $300^{\circ} \mathrm{C}$. The

\footnotetext{
* Corresponding author: E-mail: ashida@cheme.kyoto-u.ac.jp DOI: https://doi.org/10.2355/isijinternational.ISIJINT-2018-812
}

coal polymerized by the cross-links cannot melt any more over that temperature. Therefore, when added to coking coals, it prevents the coking coals' thermoplasticity.

In this study we propose to pretreat brown coals or subbituminous coals with aqueous oxidant such as hydrogen peroxide in order to convert them into thermoplastic coals by oxidative degradation reactions. Miura et al. utilized such wet oxidation for producing valuable chemicals from brown coals and showed that brown coals can oxidatively depolymerize through the treatment with hydrogen peroxide aqueous solution at 40 to $60^{\circ} \mathrm{C}^{1-4)}$ Hayashi et al. employed low temperature oxidation with $\mathrm{O}_{2}$ in aqueous phase not only for producing valuable chemicals from brown coals but also for elucidating the coal structure. ${ }^{5,6}$ In this study the depolymerization reactions are applied to produce thermoplastic coals from low rank coals. Although this treatment not only depolymerizes coal but also increases the oxygen functional groups in coals causing cross-linking reactions, the treated coals are expected to melt below $300^{\circ} \mathrm{C}$, before the cross-linking reactions occur. If this is the case, those increased cross-links may contribute to increasing mechanical strength of the produced coke. The proposed method was applied to an Australian brown coal and the validity of the method was investigated.

\section{Experimental}

\subsection{Sample}

Australian Loy Yang coal was used as a brown coal sample. 
Its elemental composition and ash content are given in Table 1. Water content of the coal was around $55 \mathrm{wt} \%$ on wet basis.

\subsection{Experimental Procedure}

The coal sample was ground into fine particles of less than $1 \mathrm{~mm}$ prior to the treatment. $5 \mathrm{~g}$ of the coal was mixed with $50 \mathrm{~cm}^{3}$ of $30 \%$ hydrogen peroxide aqueous solution in a flask connected to a gas bag. The mixture was stirred using a magnetic stirrer either at room temperature for 4,8 and $24 \mathrm{~h}$ or at $60^{\circ} \mathrm{C}$ for $0.5,1$ and $2 \mathrm{~h}$ in a water bath. After the treatment, the produced gas in the flask was purged by nitrogen gas and was collected in the gas bag. The treated coal was separated from the solution by vacuum filtration, and then dried using a vacuum oven at $65^{\circ} \mathrm{C}$ for $5 \mathrm{~h}$.

The produced gas was analyzed using a gas chromatograph (Shimadzu, GC-2014). Elemental compositions of the treated coals were measured using a CHN analyzer (Yanaco, MT-6). Functional groups in the treated coals were analyzed using an FT-IR (JEOL, JIR-WINSPEC 50). To quantify low-molecular-weight compounds in the treated coals, the treated coals were extracted by tetrahydrofuran (THF) at room temperature for $3 \mathrm{~h}$ under ultrasonic irradiation. THF soluble and THF insoluble were separated by vacuum filtration and THF insoluble was dried using a vacuum oven at $65^{\circ} \mathrm{C}$ for $5 \mathrm{~h}$. Thermal analyses of the treated coals were performed using a thermogravimetric analyzer (Shimadzu, TGA-50) and a thermomechanical analyzer (Shimadzu, TMA-50). In both analyses, the sample was heated up to $900^{\circ} \mathrm{C}$ in a nitrogen stream at the rate of $10^{\circ} \mathrm{C} / \mathrm{min}$. The thermomechanical analyzer continuously monitored a displacement depth of a rod descending into a sample bed in order to examine a thermoplastic behavior of the sample. In thermomechanical analysis, the raw or treated coal sample was placed in a pan (5.2 mm I.D. and $6.0 \mathrm{~mm}$ high) at the height of $1 \mathrm{~mm}$. The rod of $4.3 \mathrm{~mm}$ in diameter was loaded with a constant load of $0.098 \mathrm{~N}$ for the measurement.

The treated coals were then pelletized under $40 \mathrm{MPa}$ at room temperature for 1 minute and the obtained disks (diameter: $17 \mathrm{~mm}$, thickness: ca. $4 \mathrm{~mm}$ ) were carbonized in a nitrogen stream by heating up to $900^{\circ} \mathrm{C}$ at the rate of $10^{\circ} \mathrm{C} /$ min and keeping $900^{\circ} \mathrm{C}$ for $30 \mathrm{~min}$ to obtain cokes. Tensile strength of the resulting cokes was measured by a tensile testing machine (Shimadzu, AGS-J) at room temperature.

Table 1. Properties of raw coal and treated coals.

\begin{tabular}{|c|c|c|c|c|c|c|c|}
\hline \multirow{2}{*}{ Sample } & \multicolumn{4}{|c|}{$\begin{array}{l}\text { Ultimate analysis } \\
\text { [wt } \% \text {, d.a.f. }]\end{array}$} & \multicolumn{2}{|c|}{$\begin{array}{c}\text { Atomic Ratio } \\
{[-]}\end{array}$} & \multirow{2}{*}{$\begin{array}{c}\text { Ash } \\
{\left[\mathrm{wt}^{0} \%, \mathrm{~d} . \mathrm{b} .\right]}\end{array}$} \\
\hline & $\mathrm{C}$ & $\mathrm{H}$ & $\mathrm{N}$ & O (diff.) & $\mathrm{H} / \mathrm{C}$ & $\mathrm{O} / \mathrm{C}$ & \\
\hline Raw & 65.5 & 4.1 & 0.7 & 29.8 & 0.74 & 0.34 & 2.3 \\
\hline \multicolumn{8}{|l|}{ Treated coal } \\
\hline RT 4 h & 66.7 & 3.9 & 0.6 & 28.8 & 0.70 & 0.32 & 0.8 \\
\hline $\mathrm{RT} 8 \mathrm{~h}$ & 64.9 & 3.9 & 0.4 & 30.8 & 0.73 & 0.36 & 1.8 \\
\hline RT $24 \mathrm{~h}$ & 64.9 & 4.1 & 0.6 & 30.4 & 0.76 & 0.35 & 0.5 \\
\hline $60^{\circ} \mathrm{C} 0.5 \mathrm{~h}$ & 66.1 & 4.1 & 0.6 & 29.2 & 0.74 & 0.33 & 1.6 \\
\hline $60^{\circ} \mathrm{C} 1 \mathrm{~h}$ & 65.7 & 4.1 & 0.6 & 29.6 & 0.75 & 0.34 & 1.1 \\
\hline $60^{\circ} \mathrm{C} 2 \mathrm{~h}$ & 65.5 & 4.3 & 0.7 & 29.5 & 0.79 & 0.34 & 2.7 \\
\hline
\end{tabular}

\section{Results and Discussion}

\subsection{Behavior in the Wet Oxidation Treatment}

Figures 1 and 2 respectively show product yields on dry coal weight basis and on carbon basis. $\mathrm{CO}_{2}$ and water soluble organics were formed together with the treated coal. The treated coal yield decreased with the treatment time from $91.0 \mathrm{wt} \%$ for $4 \mathrm{~h}$ to $77.3 \mathrm{wt} \%$ for $24 \mathrm{~h}$ at room temperature, and from $81.7 \mathrm{wt} \%$ for $0.5 \mathrm{~h}$ to $73.5 \mathrm{wt} \%$ for $1 \mathrm{~h}$ at $60^{\circ} \mathrm{C}$. Carbon-based yield of $\mathrm{CO}_{2}$ was as low as less than $2.7 \%$ at room temperature and less than $11.5 \%$ at $60^{\circ} \mathrm{C}$, suggesting that carbon in the raw coal was mainly distributed to the treated coal and water soluble organics containing valuable chemicals. ${ }^{1-4)}$ The yields of the treated coals for room temperature, $24 \mathrm{~h}$ and for $60^{\circ} \mathrm{C}, 1 \mathrm{~h}$ were nearly equal, but the $\mathrm{CO}_{2}$ yield for $60^{\circ} \mathrm{C}, 1 \mathrm{~h}$ was three times as large as that for room temperature, $24 \mathrm{~h}$, indicating that reaction pathways were different between room temperature and $60^{\circ} \mathrm{C}$.

Table 1 shows elemental compositions of the raw coal and treated coals. The elemental compositions of the raw coal and treated coals were not so different. However, chemical structure did change with the progress of the treatment as seen in FTIR spectra shown in Figs. 3 and 4. The peak intensity at $1700 \mathrm{~cm}^{-1}$ attributed to carbonyl groups and the peak intensity at $2650 \mathrm{~cm}^{-1}$ attributed to $\mathrm{COOH}$ dimers increased with the treatment time.

To examine increase in low-molecular-weight com-

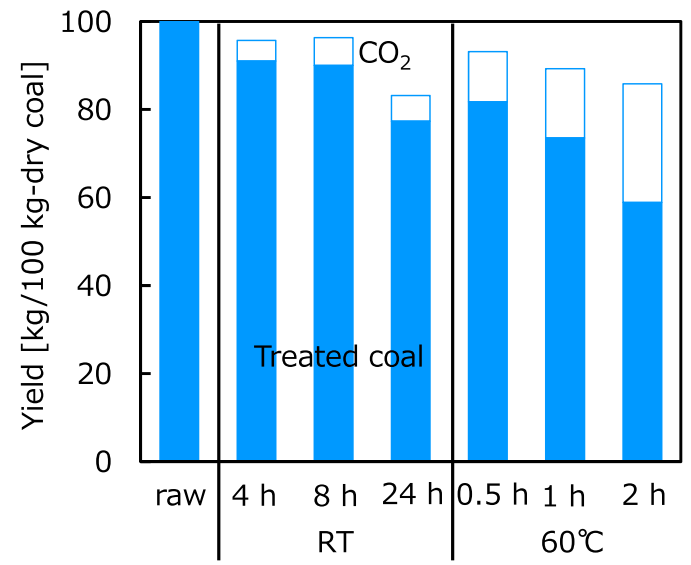

Fig. 1. Yields of the products on dry coal weight basis. (Online version in color.)

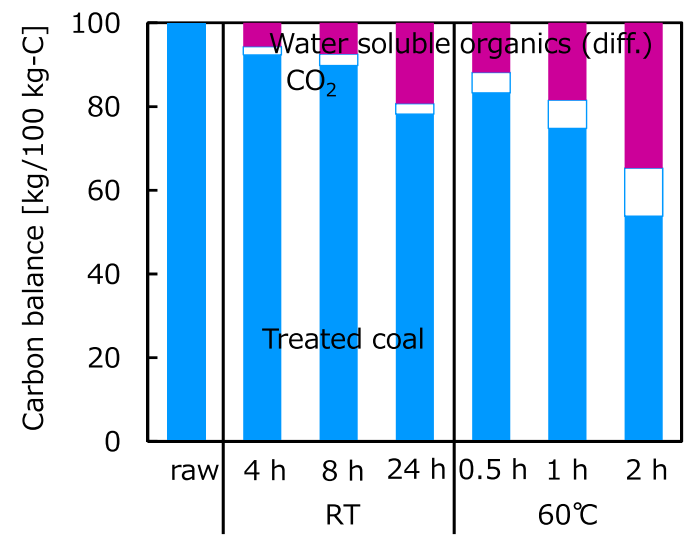

Fig. 2. Yields of the products on carbon basis. (Online version in color.) 


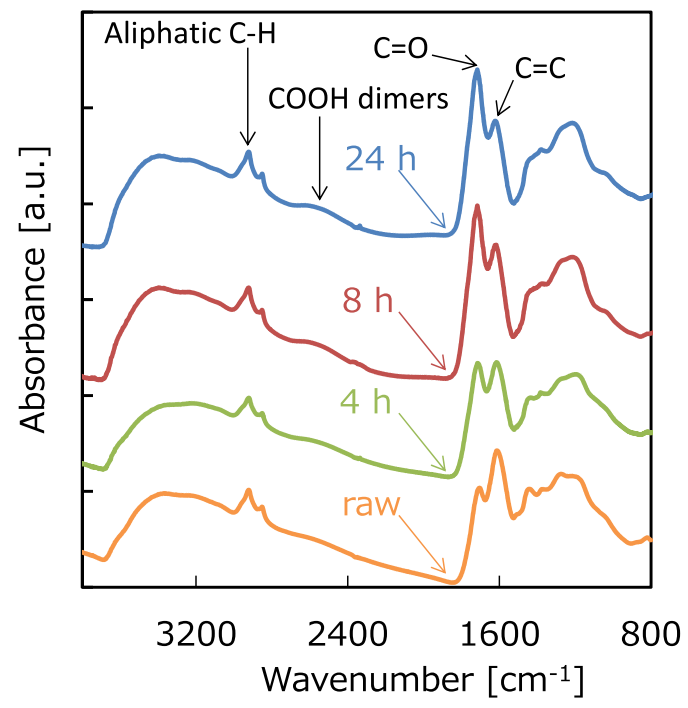

Fig. 3. FTIR spectra of the coals treated at room temperature. (Online version in color.)

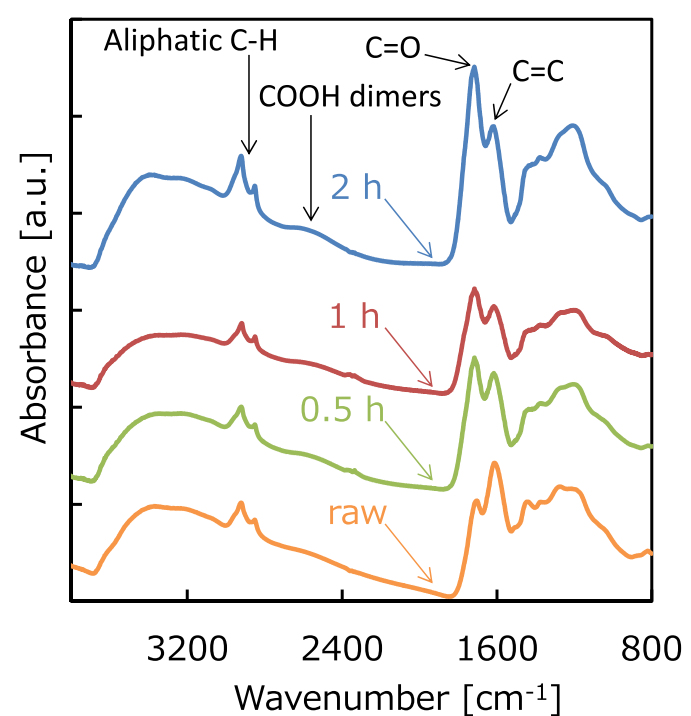

Fig. 4. FTIR spectra of the coals treated at $60^{\circ} \mathrm{C}$. (Online version in color.)

pounds by the treatment, the treated coals were extracted by THF. Figures 5 and $\mathbf{6}$ respectively show the extraction yield on raw coal basis and on treated coal basis. The extraction yield increased with increasing the treatment time on either basis and for either temperature. These results indicate that the treatment increased low-molecular-weight compounds significantly while introducing carboxyl groups, as expected. Among the conditions employed in this study, the treatment at $60^{\circ} \mathrm{C}$ gave a larger extraction yield as compared to the treatment at room temperature. Extraction yield on treated coal basis reached as large as $61.7 \mathrm{wt} \%$ for $60^{\circ} \mathrm{C}, 2 \mathrm{~h}$.

\subsection{Thermal Behavior of the Treated Coal}

Figures 7 and 8 show thermogravimetric (TG) curves and thermomechanical analysis (TMA) curves of the raw coal and treated coals. The TMA curves show that the displacement was larger for the treated coals than for the raw coal at either treatment temperature. The displacement increased with increasing the treatment time for the

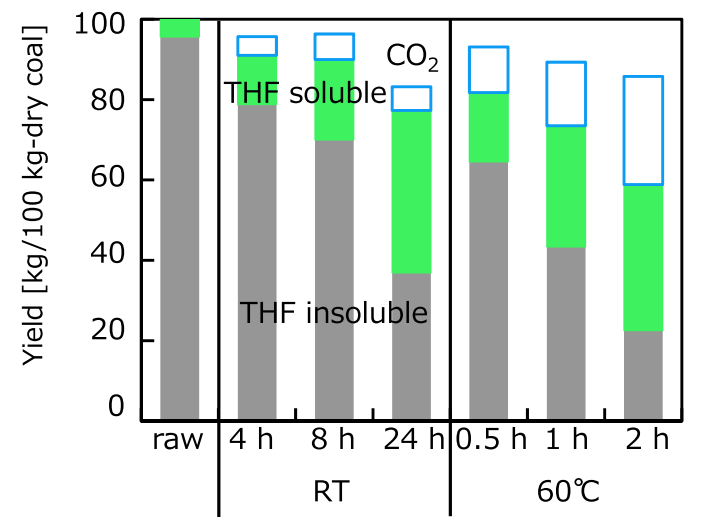

Fig. 5. Extraction yield on dry coal basis. (Online version in color.)

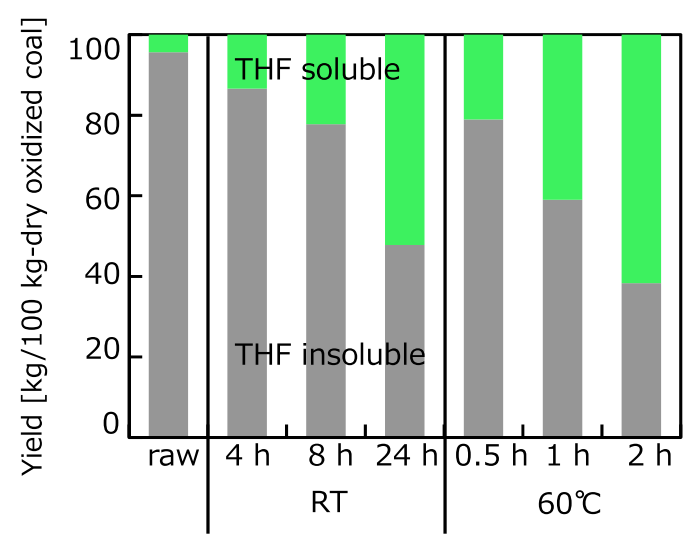

Fig. 6. Extraction yield on treated coal basis. (Online version in color.)

treatment at $60^{\circ} \mathrm{C}$ whereas the displacement was close regardless of the treatment time for the treatment at room temperature. Since the raw coal is known to have no thermoplasticity, the decrease in the normalized displacement value (TMA) for the raw coal can be judged to mainly be caused by the volume decrease due to the weight loss. For such a raw coal, the TMA curve was always well above its TG curve. However, the TMA curves for the coals treated at $60^{\circ} \mathrm{C}$ gradually got closer to their TG curves with increasing the treatment time especially below $300^{\circ} \mathrm{C}$, and the normalized displacement value (TMA) for the coal treated for $2 \mathrm{~h}$ became less than the relative weight (TG) below $300^{\circ} \mathrm{C}$, suggesting that the coals treated at $60^{\circ} \mathrm{C}$ tend to have the thermoplasticity below $300^{\circ} \mathrm{C}$. At temperature higher than $300^{\circ} \mathrm{C}$, the decrease in the normalized displacement value (TMA) for the treated coals was much less than that in the relative weight (TG), indicating the decrease in the normalized displacement was mainly caused by the volume decrease. For the coals treated at room temperature, on the other hand, the TMA curves were well above the TG curves as the raw coal. These results show that the treatment at $60^{\circ} \mathrm{C}$ was more effective in enhancing thermoplasticity than the treatment at room temperature. The difference between the treatment temperatures will be discussed later.

\subsection{Tensile Strength of Coke Prepared from the Treated Coal}

Figure 9 shows the tensile strength of cokes prepared from the raw coal and treated coals. Tensile strength of the 


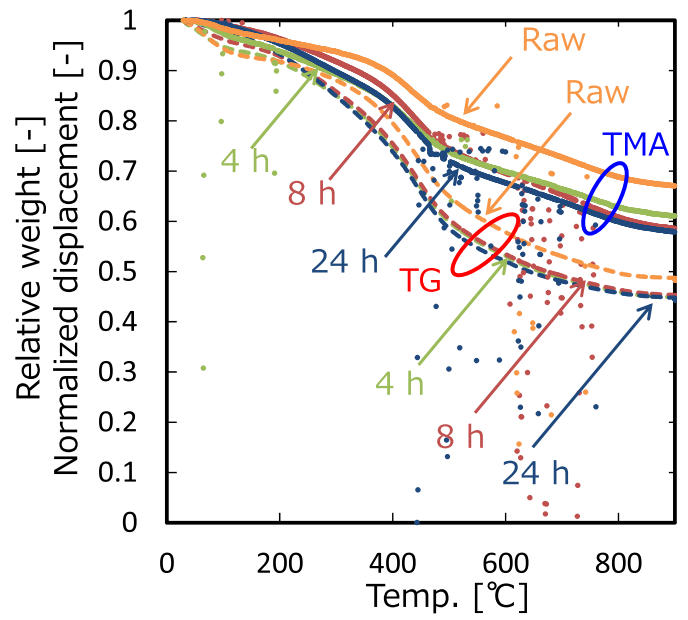

Fig. 7. TG and TMA profiles of the coals treated at room temperature. (Online version in color.)

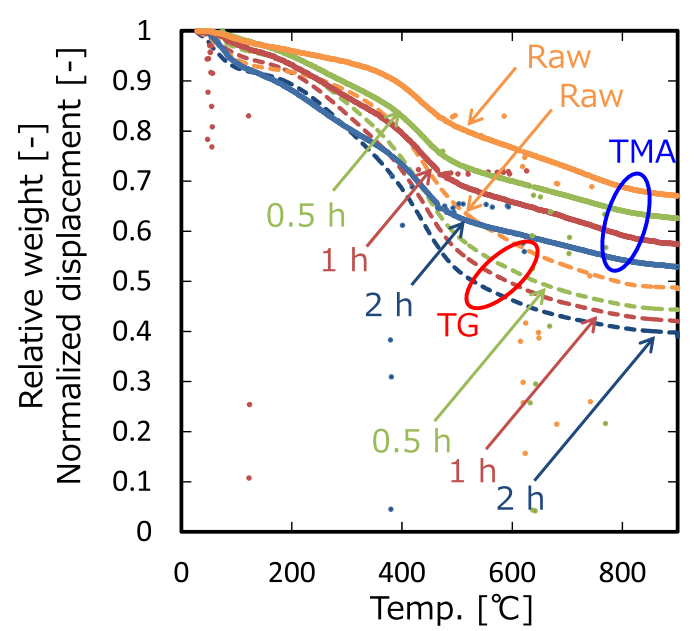

Fig. 8. TG and TMA profiles of the coals treated at $60^{\circ} \mathrm{C}$. (Online version in color.)

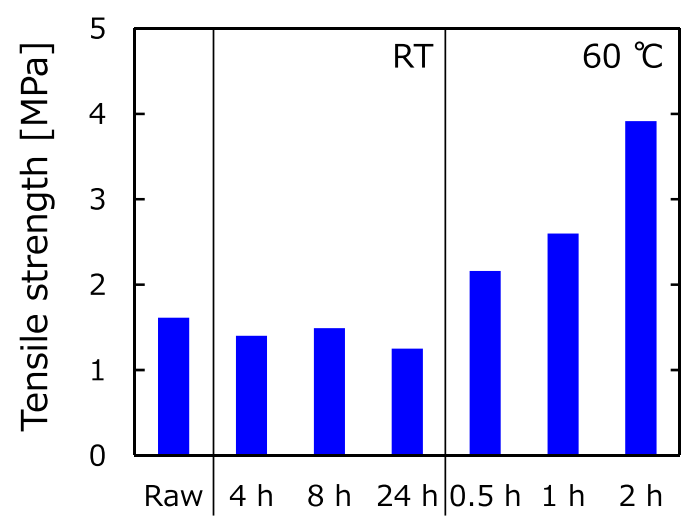

Fig. 9. Tensile strength of cokes prepared from treated coals. (Online version in color.)

cokes prepared from the coals treated at room temperature were all similar to that of the coke prepared from the raw coal, but the tensile strength of the cokes prepared from the coals treated at $60^{\circ} \mathrm{C}$ increased with increasing the treatment time and reached the level of a commercial coke, $4 \mathrm{MPa}$. This increase in the tensile strength is in good agreement with the increase in the THF extraction yield (Fig. 6) and the increase in displacement in the TMA profiles (Fig. 8). It can be concluded that the improvement in tensile strength of cokes was realized by depolymerization of coal through wet oxidation. For the treatment at room temperature, on the other hand, the tensile strength of the cokes did not increase regardless of the increase in the THF extraction yield (Fig. 6). Although the THF extraction yield for the treatment at room temperature for $24 \mathrm{~h}$ was rather close to that for the treatment at $60^{\circ} \mathrm{C}$ for $2 \mathrm{~h}$, the tensile strength of coke for the treatment at $60^{\circ} \mathrm{C}$ for $2 \mathrm{~h}$ was three times as high as that for the treatment at room temperature for $24 \mathrm{~h}$. From the viewpoint of chemical structure, these treated coals were a little different; the peak intensities at $2840 \mathrm{~cm}^{-1}$ and $2920 \mathrm{~cm}^{-1}$ attributed to aliphatic $\mathrm{C}-\mathrm{H}$ groups are more distinct for $60^{\circ} \mathrm{C}, 2 \mathrm{~h}$ than those for room temperature, $24 \mathrm{~h}$, suggesting that ring opening reactions were more pronounced for the treatment at $60^{\circ} \mathrm{C}$. There might be both a positive effect and a negative effect by the treatment. The positive one was depolymerization confirmed by THF extraction results for the both treatment temperatures. The negative one could be an increase in the cross-linking points, in other words, hydrogen bondings. For the coal treated at room temperature, these opposite effects cancelled each other, resulting in no apparent effect on thermal property. For the coal treated at $60^{\circ} \mathrm{C}$, more ring opening reactions suggested by the FTIR results might have contributed to weakening the whole strength of hydrogen bondings since hydrogen bondings are generally stronger for phenolic hydroxyl groups than those for alcoholic hydroxyl groups, which could eventually have suppressed the negative effect and enhanced thermoplasticity. But further investigation is necessary to clarify the effect of chemical structure.

\section{Conclusions}

We have proposed to pretreat low rank coals by oxidative degradation reactions with aqueous oxidant such as hydrogen peroxide in order to convert them into thermoplastic coals suitable for coke making. It was shown that a pretreatment with hydrogen peroxide aqueous solution at $60^{\circ} \mathrm{C}$ effectively increased low-molecular-weight compounds in a brown coal and enhanced thermoplasticity of the coal. Tensile strength of the cokes prepared from the pretreated coal increased with increasing the oxidation time at $60^{\circ} \mathrm{C}$ and reached the level of a commercial coke. It was thus suggested that the wet oxidation was effective as a pretreatment for producing cokes from low rank coals.

This work has been done in the ISIJ research group on "Element Technologies for a New Coke-Making Process" (Chief Manager: Prof. Hideyuki Aoki, Tohoku University). The authors are grateful to all the research group members.

\section{REFERENCES}

1) K. Miura, K. Mae, H. Okutsu and N. Mizutani: Energy Fuel., 10 (1996), 1196.

2) K. Mae, T. Maki, J. Araki and K. Miura: Energy Fuel., 11 (1997), 825 .

3) K. Mae, T. Maki, H. Okutsu and K. Miura: Fuel, 79 (2000), 417

4) K. Mae, H. Shindo and K. Miura: Energy Fuel., 15 (2001), 611.

5) J. Hayashi, Y. Matsuo, K. Kusakabe and S. Morooka: Energy Fuel., 11 (1997), 227.

6) J. Hayashi, S. Aizawa, H. Kumagai, T. Chiba, T. Yoshida and S. Morooka: Energy Fuel., 13 (1999), 69. 